\title{
Virtual Learning Environments as a Supplement to Traditional Teaching
}

\author{
Joana LIPEIKIENE் \\ Institute of Mathematics and Informatics, Vilnius Pedagogical University \\ Goštauto str. 12, LT-2600 Vilnius, Lithuania \\ e-mail: joanal@ktl.mii.lt
}

Received: April 2003

\begin{abstract}
Many factors influence teaching nowadays. Numbers of students are increasing, some students pay for studies and require more flexible teaching, more students have access to Internet, the learning material is changing rapidly (especially of subjects, related to information technologies), publishing industry is slow and expensive. All that stimulates usage of modern technologies in education. Virtual Learning Environments (VLEs) is one of the forms of e-learning. They open new ways of teaching and communication such as management of online learning, course delivery mechanism, communication and assessment tools, student tracking, access to electronic resources, etc. All these means correspond to the needs of contemporary teachers and students. VLEs have primarily been used for distance education but they are being used increasingly as supplement of traditional classroom based education. The author is interested in this latter aspect of VLEs.

The paper briefly reviews main types of Virtual Learning Environments and analyses the use of VLEs in Lithuania. The results of the investigation of two different learning environments - traditional (Web CT) and collaborative (FLE3) at the Vilnius Pedagogical University are also discussed in the article.
\end{abstract}

Key words: e-learning, web based learning, virtual learning environments.

\section{Introduction}

Contemporary teaching has to withstand much pressing, especially the teaching of informatics subjects. Namely:

- increasing number of students;

- increasing number of extramural and evening classes students;

- some students partially pay for education and require flexible (time-wise and placewise) teaching;

- increasing computer literacy of students;

- networked computers;

- rapidly changing teaching contents;

- slow and expensive publishing industry.

All these reasons require using new forms of teaching. E-learning changes education and training radically, opens new ways of teaching. It is defined as any use of information 
technologies for learning and "may encompass multiple formats and hybrid methodologies, in particular, the use of software, Internet, CD-ROM, online learning or any other electronic or interactive media" (E-learning and training in Europe, 2001, p. 5). Web based learning usually is equated with the use of Internet for teaching purposes. "The Internet is perhaps the most transformative technology in history, reshaping business, media, entertainment, and society in astonishing ways. But for all its power, it is just now being tapped to transform education" (The Power of the Internet for learning, 2000). Today's teachers have a great variety of Internet based tools available to them for supporting their classes. As both teachers and students gain greater access to advanced hardware and network connection, the expansion of web based teaching and learning is proceeding rapidly.

Virtual Learning Environment (VLE) is one of the web based learning forms. One can imagine the relationship between Virtual Learning Environments, web based learning and e-learning as it is shown in Fig. 1. So web based learning is a subset of e-learning, which includes Virtual Learning Environments.

Various software packages that control the learning process or individual tools that provide some features of online learning could be regarded as Virtual Learning Environments (Britain, 1999), but, traditionally, VLEs provide not only web pages with course material, but at least some course management and communication tools within the environment. There is a great variety of software for creating of learning environments. Several Virtual Learning Environments have been used in Lithuania's higher education. In order to apply Virtual Learning Environments in teaching it is essential to perform diverse investigations of their capabilities.

\section{The goals of the research are}

- to review the main types of VLEs and to analyse their use in Lithuania: what VLEs at what level are used in Lithuania at present.

- to investigate some aspects of practical VLEs use: what features of VLEs are essential in the use of VLE as supplement to traditional teaching.

Two types of VLEs (traditional and collaborative) software were used to develop the learning environments for the research purposes. The created VLEs were used for teaching at the Vilnius Pedagogical University. Questionnaires, statistical data from the automatic student tracking tools and qualitative students' evaluations of the environments were used to draw conclusions.

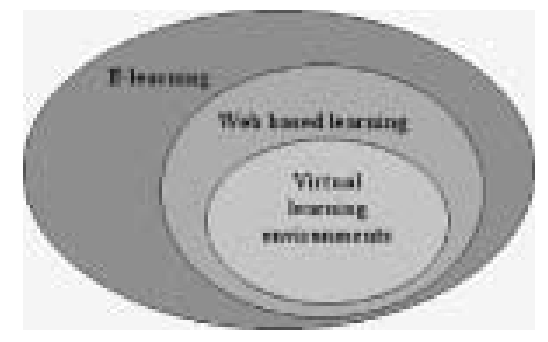

Fig. 1. The relationship of Virtual Learning Environments to web based and e-learning. 


\section{Basic Types of Virtual Learning Environments}

Following the emergence of the Internet in the early 1990s, many new tools have been developed for education. Since the mid-1990s, the education software products labelled Virtual Learning Environments have appeared with the aim of supporting learning and teaching activities via the Internet (Milligan, 1999). Strictly speaking, the term VLE describes software, which resides on a server, and is designed to manage various aspects of teaching: a course delivery mechanism, student tracking, assessment, access to the resources, etc. The essential features of traditional VLE, integrating the means of up-to-date information technology (IT) tools are:

- access control - usually password based;

- delivery and management of well prepared course material, which can be changed, renewed or supplemented effectively;

- use of all types of physical media: text, 2D and 3D graphics, animation, digital audio, digital video, virtual reality;

- links to digital libraries and other important information on the Internet;

- automatic glossaries, indexes, search;

- communication tools - e-mail, chats, presentations, announcements, discussions inside the environment;

- connection to software necessary for learning (if any);

- personal space for students to exchange and store materials;

- automatic assessment, usually self-assessment tools;

- student tracking, collation of marks, statistical information for the teacher about the learning process.

Now there are many Virtual Learning Environments, offering different sets of features mentioned above (Britain and Liber, 1999; Course Management Systems, 2003). The choice of an environment and the set of features depend on many factors, such as the course subject, delivery mode, purposes of the course, cost, etc. Table 1 presents an approximate view of VLE types. It would be complicated to present all the available Virtual Learning Environments, so only some representatives, most typical and popular in Lithuania, are mentioned in the table. The classification is not strict, as there are environments that have some specific features and, maybe, do not belong to any of the types. But this approximate view gives at least some picture of the great variety of modern VLEs.

VLEs have been used primarily for distance education, but they are being used increasingly as a supplement to traditional classroom based teaching (Clements and Smalley, 2000). Educational institutions seek ways to use technology not only for distance learning but to make teaching more effective on-campus as well. We were interested more in the latter aspect of learning environments. Further we discuss the use of Virtual Learning Environments in Lithuania, present the results of investigation of traditional VLE Web CT and discuss the use of collaborative Virtual Learning Environment FLE3. 
Table 1

Approximate classification of VLEs

\begin{tabular}{lll}
\hline Virtual Learning Environments & Basic feature & Representatives \\
\hline Traditional & Learning material-based & $\begin{array}{l}\text { Web CT, Learning Space, } \\
\text { Luvit, Top Class }\end{array}$ \\
Collaborative & Learner-based & COSE, CoMentor, FLE3 \\
Home-made & Can be created from smaller & CVU, Nathan Bodington, \\
& parts according to needs & First Class \\
\hline
\end{tabular}

\section{Virtual Learning Environments in Lithuania}

Virtual Learning Environments were begun to use in higher education of Lithuania a few years ago. They first were investigated at the Vilnius University and at the Kaunas University of Technology: some investigations of traditional learning environments Web CT (www . webct. com), Top Class (http: //www . wbt systems . com), Luvit (http://www . luvit. com) and Lotus Learning Space (http://www. lotus.com) were performed at the Vilnius Distance Education Centre, the Kaunas Distance Education Study Centre, the Vilnius Gediminas Technical University, and at the Institute of Mathematics and Informatics (Abarius et al., 1999; Targamadze et al., 1999; Janilionis, 2000; Kulvietienè and Šileikienè, 2001; Lipeikienè, 2001; Lipeikienè et al., 2002). It seems Web CT took the first place, and the two distance learning centres mentioned above use mainly Web CT now. Tens of various courses developed in the Web CT environment are registered on the servers of the Vilnius Distance education centre and the Kaunas Distance education Study Centre. Some of the courses are developed by the teachers of other institutions, as these distance learning centres train teachers not only of their own universities. Web CT facilities are wide and attractive. The truth is that most of the courses use only a small part of Web CT capabilities: delivery of the material, some course management and tests, at the most. Despite the variety of learning environments that have been used in Lithuania, these features (course material with tests) are dominant. It is natural - all teachers are busy and try to do the main job - to present rapidly changeable and renewable course materials on the web for self-dependent learning and not to try more features, as this requires much time. However, if the Web CT spreads in Lithuania as it does now, most likely, more and more facilities of virtual environments will be used.

Web pages with the course material and tests are characteristic not only of Web CT users, but also, for example, of distance learning courses - web sites created at the two different departments of the Gediminas Technical University (http://www.el.vtu.lt/dist_mok, http://www.vtu.lt/dcm01/pagrindinis.htm) or courses at the Vytautas Magnus University residing on the FirstClass server (http: / / fc.vdu.lt). The server (Intranet) is used for communication and information spread at the Vytautas Magnus University. All course materials that are published on the server are mainly used as a supplement to classroom based teaching for self-dependent studies. Students can communicate within the Intranet, create their 
own web pages, organise discussions, conferences, etc. Teachers publish material of their courses for self-dependent studies.

Thus, most types of Virtual Learning Environments have found their way to Lithuania's higher education institutions. Let us look at the VLE in more detail.

\section{Traditional Virtual Learning Environments}

Virtual Learning Environments were developed to support learning by all possible IT. So it is natural that they integrate all possible means of learning, useful for the course subject. All the traditional VLEs have the same specific feature - the learning material is at the centre of the environment and all other means manage the delivery of the learning material, help to acquire the material. It is typical of the most popular Virtual Learning Environments, such as Web CT , Top Class, Luvit, Lotus Learning Space, etc.

The most typical traditional virtual environment is Web CT. It supports all the means of VLEs enumerated in the Section 2. Various facilities are useful in delivering different courses. We chose the programming language $\mathrm{C}++$ course for creating of the learning environment as problems of object oriented programming teaching are urgent and are often discussed in scientific literature. For example, it is really not impossible to show on a blackboard even simplest programs for Windows, as they are very long. Teaching by old methods, it is impossible to create programs during a short time of laboratory practice.

The $C++$ learning environment was developed at the Institute of Mathematics and Informatics on the Web CT server of the Vilnius Distance Education Centre. The environment was meant for use as a supplement to traditional classroom based $\mathrm{C}++$ teaching. Fig. 2 shows the home page with links to the tools that were created in the Web CT environment. We used all essential facilities of Web CT in order to solve specific objectoriented programming for Windows teaching problems (Lipeikiené, 2001; Lipeikiené, 2002). Borland C++ software was integrated into Web CT. Thus, the course material is related to programs - samples. Students can see a long text of programs that cannot be presented on the blackboard delivering lectures. A learner can load samples and see the results, reading the course material immediately. Long programs for Windows can be created copying parts of the available programs during laboratory practice. Index and Search are helpful in acquiring the material. Communication tools are available, though they are not so important in supplementary use of the environment. 15 tests have been created for self-assessment.

Practical use and investigation of the $\mathrm{C}++$ learning environment. The $\mathrm{C}++$ learning environment has been used as a supplement of $\mathrm{C}++$ programming teaching at the Vilnius Pedagogical University for two academic years. 30 postgraduate students had access to the learning environment and were free to use it wherever and whenever they wanted. At the end of both school years, the students filled in questionnaires about the learning environment. Student tracking facilities - statistical data about the learning process were received from the Web CT Manage Course tool. So both data were used to summarise students' opinion and the efficiency of the environment as a supplement to traditional 


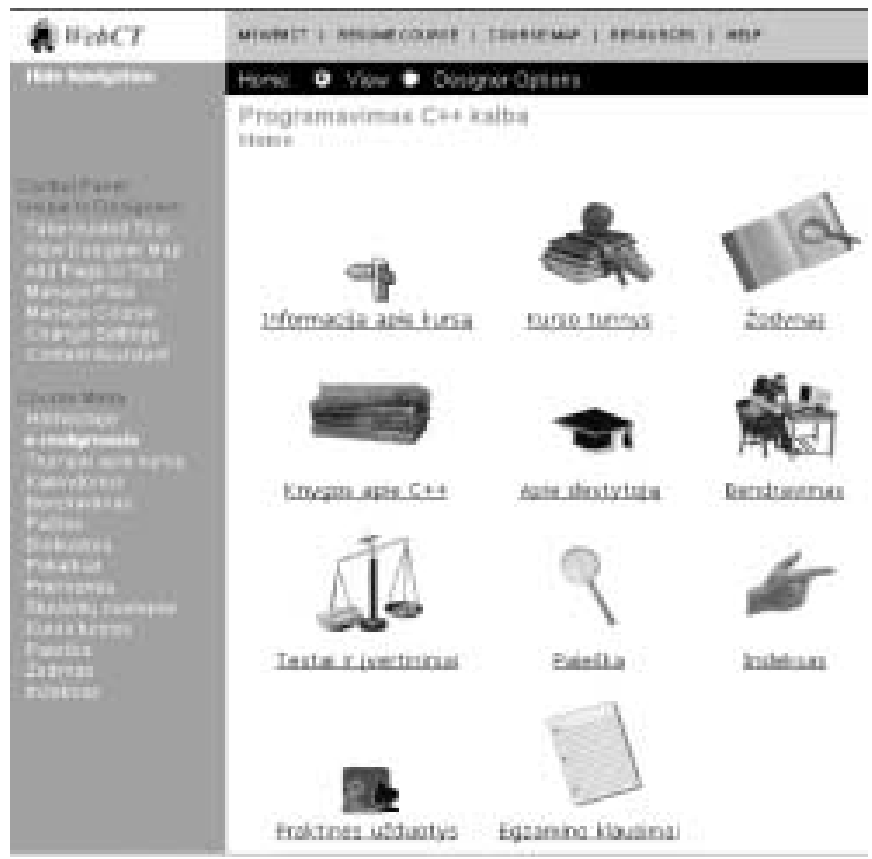

Fig. 2. Home page of the C++ learning environment. (Information on the Course, Course contents, Glossary, References, About the Teacher, Communication, Tests and Assessment, Search, Index, Practical tasks, Examination topics)

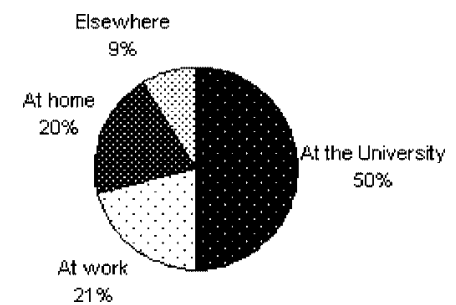

Fig. 3. Data where students used the $\mathrm{C}++$ learning environment.

teaching. The results of the two years were similar. They were summarised and are presented here as an average of two - year data. Fig. 3 presents the data, where students used VLE. Fig. 4 shows the frequency of students' work in the environment.

A repeating result on the use of individual parts of VLE (Fig. 5) shows the students' view to the usefulness of separate parts in the supplementary learning. Many students indicated that such parts as Index, Glossary, and Search would be useful after some time, when they forget the material, but now that they have lectures in the classroom, these parts are not so important. The surprising results (but the repeating ones again!) have been received after the students evaluated the use of "live" samples in the course material. The first year 12, the second year 9 students noticed that they had even not tried to load the samples. The general evaluation of the learning environment was good: $98 \%$ of students 


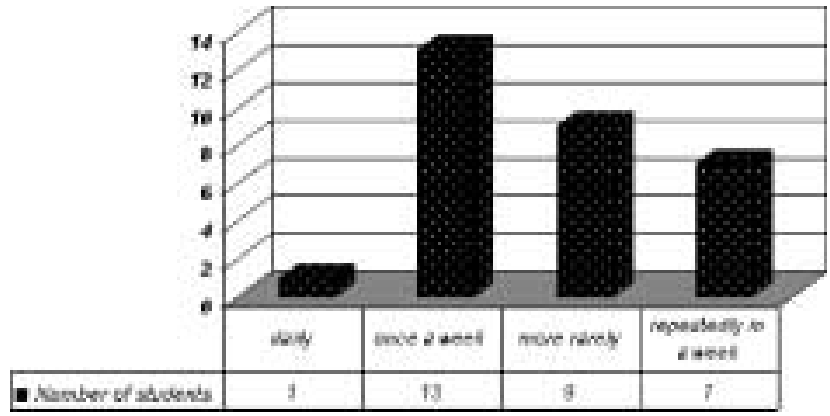

Fig. 4. Answers of the students how often they used the $\mathrm{C}++$ learning environment.

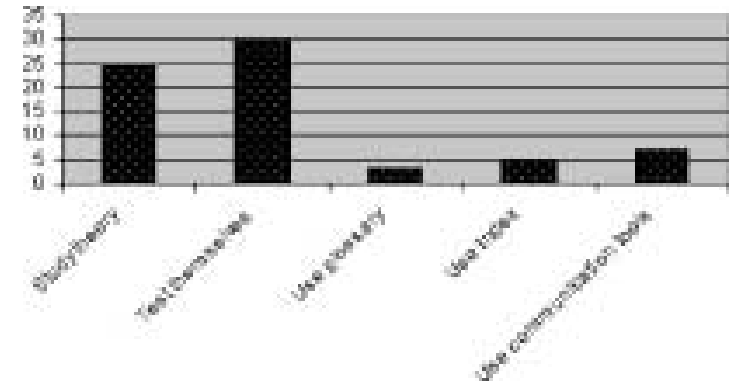

Fig. 5. Data how students used separate parts of the environment.

regard VLE useful for their studies.

Student tracking in Web CT takes place automatically, it does not require any efforts, but is useful for a teacher. Statistical data on student work in the environment, assessment, presented as histograms, demonstrate what are students interested in most and which sections of the course are most important for them.

The critical evaluation of practical supplementary use of the $\mathrm{C}++$ learning environment together with traditional learning displayed that some parts of the learning environment (Index, Glossary, Search, Communication tools) were not very important. The most valuable parts, in students' opinion, are electronic course material and self-assessment tools. Student tracking, statistical data on student work are most valuable for a teacher.

\section{Collaborative Learning Environments}

Alternative models of VLE instead of learning material place the learner at the centre of the environment. A learner gets tasks, links to resources, and communication tools. The main features of these environments are communication, collaborative learning, collecting together a set of relevant resources and building knowledge together. While developers of traditional learning environments give for learners all possible learning material, the collaborative environments use in the main collaborative tools. The designers of the environments emphasise - knowledge is not of great value at present. The most 
important thing is to acquire learning methods and habits to find self-dependent solutions. Collaborative nature of learning is introduced, for example, in (Hakkarainen, 2002; Bereiter, 2002). So a learner searches for resources (or use links to resources that are presented by the teacher) or relevant material, adds his own materials and shares with other learners. So he yields input from his own experience. A course is viewed as a group of students to whom learning opportunities are assigned rather than as a body of content to which students are assigned. Students have really to study and deepen their understanding. But developing of collaborative environments requires from the teacher much work - to organise a research kind of learning process, to motivate students to work this way, to prepare plans, problems, questions, to quid the learning flexibly from the beginning till end of the course. CoMentor (http:// comentor.hud.ac.uk), COSE (http: //web.staffs.ac.uk/COSE) and FLE3 (http: / / fle3.uiah.fi) learning environments could be mentioned as the examples of this type of VLEs though each of the collaborative environments is different and has its own specific features.

CoMentor is software, which allows creating collaborative Virtual Learning Environment for discussions and collaborative learning along with resources to support learning. The main parts of the environment are described in the environment's map (Fig. 6). They show organisation of work and main possibilities. The CoMentor environment uses a graphic metaphor of a series of linked rooms for individual and collaborative work (synchronous communication - chat facilities are always on screen). The individual work area contains tools for working within the system, whilst the group work area provides support for collaborative learning and communication. The resource area contains individual learning resources made available by course teacher.

CoMentor is particularly aimed at arts, the humanities and social science courses, in which the learning centres on discussion and textual resources. We have investigated more two other collaborative learning environments - COSE and FLE3.

COSE (creating of study environments) is typical software for creating a learner-based environment. COSE provides students with a set of tools to construct their knowledge around the resources, which are presented as 'pagesets'. These pagesets may include local resources, links to external materials, assignments etc. The view of the COSE Management tools is presented in Fig. 7. There one can see the main facilities of the environment.

Learners can also produce page sets, which are available for viewing by all groups of students. COSE allows sharing of the content files, documents, and annotations between the tutor and learners. A chosen content could be published onto CD-ROM. There is a possibility to send e-mails from within COSE to a preferred e-mail account. COSE tracks learner activities and provides feedback on the learner and group use of contents

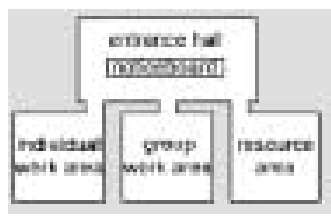

Fig. 6. Map of CoMentor learning environment. 


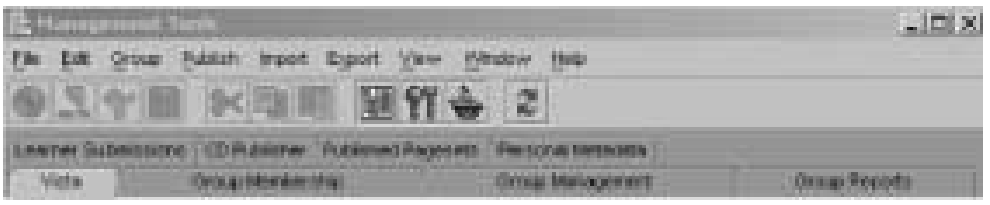

Fig. 7. The view of the COSE Management tools.

or taking tests. We examined the trial version of COSE, trying its facilities and comparing with FLE3.

FLE (future learning environment) is a more specific representative of collaborative learning environments. It is based on a pedagogical model of progressive inquiry (see web site of the Centre for Research on Networked Learning and Knowledge Building for Progressive inquiry description). As the authors of FLE3 write in the practical tips for teachers, "for a more traditional teacher, instruction and didactic-based training FLE3 might not be the right tool". "FLE3 does not lend itself easily to material based learning, where obligatory course material is delivered and then questioned. Nor does FLE3 offer much of a support for teacher centered models, where teacher tells learners exactly what to do and when to do" (Leinonen et al., 2002). FLE3 supports collaborative learning, where students and teacher coordinate efforts to solve problems and build knowledge together. The discussion tool supports constructivist learning built around a problem-based pedagogic model. Relatively speaking, COSE is more similar to traditional learning environment than FLE3. We present more common and different features of the two environments in the Table 2.

Since FLE3 is free, we downloaded the relevant software for use of this system at the Institute of Mathematics and Informatics. An installation and acquiring of the system took some time. We carried out some experiments with the environment at the Vilnius Pedagogical University with the second year students learning the course of The Computer Mathematics Systems. The created environment was used as a supplement to traditional teaching of some advanced topics. The environment was suggested for voluntary learning of some additional topics that could not be found in the textbooks. Students worked on the topics of comparing different computer mathematics systems. For example, one topic was "The differences of 3D-graphics in DERIVE, MAPLE and MATLAB", the other "Compare calculus in DERIVE and MAPLE". After the teacher enters the environment, he sees WebTop, Knowledge Building, Jamming (Improvisations), Course Management and User Management tools, while students see only WebTop, Knowledge Building and Jamming tools.

WebTops can be used by teacher and students to store different items (documents, files, links, and knowledge building notes) related to their studies. Students can share the contents of their personal folders with other students or the teacher (students can enter any of other student WebTop, but can not change anything there). Learners can create a personal home page with a picture and personal information. Students can collaboratively author a document, image, or a sound file. Knowledge building page is the place, where students put their notes related to the special topic according to context. The teacher 
Table 2

The features of two collaborative Virtual Learning Environments

\begin{tabular}{|c|c|}
\hline FLE3 & COSE \\
\hline \multicolumn{2}{|c|}{ Administrators can protect access to individual courses with username and password } \\
\hline \multicolumn{2}{|c|}{ Administrator can assign different levels of access to courses } \\
\hline Students have access to an online help manual & $\begin{array}{l}\text { The system includes an online course. Stu- } \\
\text { dents have access to a course on the system } \\
\text { documentation. }\end{array}$ \\
\hline $\begin{array}{l}\text { Discussion can be viewed by date, by thread, and } \\
\text { by the type of post (problems, explanations, com- } \\
\text { ments, evaluations, summaries) }\end{array}$ & $\begin{array}{l}\text { Discussion forums can be viewed by date and by } \\
\text { thread, teachers may create separate discussion } \\
\text { environments for small groups }\end{array}$ \\
\hline \multicolumn{2}{|c|}{ Students can share the contents of their personal folders with other students } \\
\hline It does not support internal mail & $\begin{array}{l}\text { Students must have an external Internet email ad- } \\
\text { dress. Students use a searchable address book to } \\
\text { email individuals and groups. }\end{array}$ \\
\hline It does not support real time chat & There is a basic chat tool \\
\hline It does not support self-assessment & $\begin{array}{l}\text { Instructors can create automatically scored mul- } \\
\text { tiple choice questions, the system can display } \\
\text { teacher - created feedback }\end{array}$ \\
\hline It does not support student tracking & $\begin{array}{l}\text { Teachers can get reports showing the number of } \\
\text { times each student or all students in a course ac- } \\
\text { cessed the course contents, course assessment and } \\
\text { self-assessments. }\end{array}$ \\
\hline $\begin{array}{l}\text { The software is free and available under Open } \\
\text { Source License }\end{array}$ & $\begin{array}{l}\text { The software is free and distributed under GNU } \\
\text { Public license }\end{array}$ \\
\hline
\end{tabular}

first of all presents the context. The short and full descriptions of the topic begin the discussion. As one can see from Table 2, FLE3 (according to its pedagogical model) lacks student tracking and assessment tools - the features that are often very useful.

It should be noted that the teacher has much work to organise learning in FLE3: he have to set up course context (the tasks, problems, questions), to guide students to search and collect relevant information from web, library, books, (in our case also - glossaries of computer systems), to watch the learning process and to take part in it during all study semester. As taking part in the experiment was voluntary, only 19 students of 104 took part in it. Though the environment is partly localised, most students indicated that English language of the resources (for example, glossaries) was the reason of their refusal to take part in the study. Those, who decided to study in the environment, worked mostly in the classroom during laboratory practice. Minority worked at home. Students got into the spirit of the environment, tried various capabilities, gathered much material successfully. But we were not able to perform relevant investigation of the environment in practice because of technical reasons - very slow loading of the environment pages. The students recognised that the environment is interesting and useful learning tool but all of them expressed disappointment because of the slow work of the environment.

The third type of learning environments could be distinguished - so called home-made environments, which are created from smaller parts according to teaching needs and they 
could be a small system providing only necessary means. Such learning environments can be created, using Clyde Virtual University (http://cvu.strath.ac.uk), Nathan Bodington Building (http://www.tlsu. leeds . acuk/nathanbodington.html) or FirstClass (www.firstclass.com) software.

\section{Conclusions}

Virtual Learning Environments are increasingly becoming an important part of teaching in Lithuania nowadays. They are used not only in distance education, but in traditional teaching as well. The use of VLEs as a supplement of traditional teaching makes teaching more flexible. Some universities in Lithuania have already got VLE in place. Many teachers have prepared their courses in the environments and use VLEs at different levels. Levels of use of VLEs are determined by what features are used:

- delivery of learning material and resources online;

- self-assessment with automated marking;

- communication tools;

- student tools - individual student home pages, a site for uploading coursework etc.;

- anagement and tracking of students.

Most of VLEs in Lithuania use the simple level, including the first two features. Our two - year investigation of traditional VLE (Web CT) showed that for students who simultaneously get traditional teaching at the classroom, these two features are essential. Students preferred the electronic learning material and self-assessment. Though, if there is a possibility to have completely integrated means, they enrich teaching and are undoubtedly useful.

The representative of other VLEs type - collaborative learning environment FLE3 is based on different pedagogical model and add specific aspects for teaching, placing a learner at the centre of the environment and giving various means of communication for the collaborative learning. Students and teacher coordinate efforts to solve problems and build knowledge jointly. We used FLE3 as a supplement to traditional teaching of some advanced topics. Students recognized that the environment is interesting and useful learning tool, but the investigation of FLE3 was not exhaustive because of technical reasons slow work of the environment.

\section{References}

Abarius, P., M. Juzonytė, M. Mačiulis and V. Satkauskas (1999). Web kursų irankių tinkamumas kursams ruošti (in Lithuanian, Practicability of Web course development tools). Vilnius University.

Britain, S., and O. Liber (1999). A Framework for Pedagogical Evaluation of Virtual Learning Environments. http: //www.jtap.ac.uk/reports/htm/jtap-041.html

Bereiter, C. (2002). Education and Mind in the Knowledge Age.

http: //www.observetory.com/carlbereiter/

Clements, M., and M. Smalley (2000). Opportunities to enhance the student learning experience using a Virtual Learning Environment. In P. Davies, S. Hodkinson and P. Reynolds (Eds.), Innovative Approaches to Learning and Teaching in Economics and Business Higher Education, Staffordshire University Press, Stoke on Trent. 
Course Management Systems. Product Information (2003).

http://www.edutools.info/course/productinfo/index.jsp

E-learning and training in Europe (2001). Cedefop Reference Series; 26. Luxembourg: Office for Official Publications of the European Communities.

Hakkarainen, K., Paavola, S. and L. Lipponen (2002). Collaborative nature of Learning and Cognitive Growth. Centre for Research on Networked Learning and Knowledge Building.

http://www.helsinki.fi/science/networkedlearning/eng/delete.html

Janilionis, V. (2000). Statistikos distancinio mokymo kursų ruošimas (in Lithuanian, Development of distance learning courses on statistics). Lietuvos matematikos rinkinys, 40, 209-214.

Kulvietienè, R., and I. Šileikienè (2001). LearningSpace: problemos ir patirtis (in Lithuanian, LearningSpace: problems and experiences). Lietuvos matematikos rinkinys, 41, 303-307.

Leinonen, T., Mielonen S., Pietarila J., Kekkonen, I., Kligyte G. and T. Toikkanen (2002). Practical tips for teachers. http://fle3.uiah.fi/how_to_use_fle3_on_course.html

Lipeikienè, J. (2001). Mokomoji aplinka objektinio programavimo dèstymui (in Lithuanian, Object-oriented Programming Learning Environment). Lietuvos matematikos rinkinys, 41, 308-313.

Lipeikienè, J. Kalpaitė, K. and A. Kluonytė (2002). Mokomosios aplinkos objektinio programavimo dėstymui tyrimas (in Lithuanian, Research of the Object-oriented Programming Learning Environment). Lietuvos matematikos rinkinys, 42, 260-266.

Lipeikienè, J. (2002). C++ Learning Environment. In Proceedings of the III International Conference "Teaching Mathematics: Retrospective and Perspectives", pp. 112-115.

Milligan, C. (1999) Virtual Learning Environments in the Online Delivery of Staff Development. Institute for Computer Based Learning. Heriot-Watt University. http: //www.jisc.ac.uk/ jtap/

The Power of the Internet for Learning. Final Report of Web-Based Education Commission (2000). http: / / www.ed.gov/offices/AC/WBEC/FinalReport/

Targamadzė, A., E. Normantas, D. Rutkauskienė and A. Vidžiūnas (1999). Naujos distancinio švietimo galimy$b \dot{e} s$ (in Lithuanian, New Distance Education facilities), Vilnius.

J. Lipeikienè is a doctor of technical sciences, a senior researcher of the Recognition Processes Department at the Institute of Mathematics and Informatics and an Associate Professor at the Informatics Department of Vilnius Pedagogical University. Her scientific interests embrace processing of random signals, including speech signals, methods for determination of change points in the properties of random processes, modern technologies in education.

\section{Virtualios mokomosios aplinkos kaip tradicinio mokymo papildymas}

\section{Joana LIPEIKIENE்}

Šių dienų mokymą veikia daug veiksnių: didejja studentų skaičius, kai kurie studentai moka už mokslą ir nori lankstesnio mokymo, vis daugiau studentu gali naudotis Internetu, mokymo turinys greitai keičiasi (ypač dalyku, susijusių su informacinėmis technologijomis), vadovėlių leidyba yra lèta ir brangi. Visa tai skatina šiuolaikinių informacinių technologijų naudojimą švietime. Virtualios mokomosios aplinkos (VMA) yra viena iš elektroninio mokymo formu. Jos atveria naujus mokymo ir bendravimo kelius: siūlo mokymo Internete administravimo, kurso teikimo mechanizma, bendravimo, automatinio vertinimo, studentų darbo stebejimo priemones, elektroninių resursų prieigas ir t.t. Šios priemonès atitinka šiuolaikiniu dèstytoju ir studentu poreikius. VMA pirmiausiai buvo pradetos naudoti nuotolinèms studijoms, bet jos vis daugiau naudojamos kaip tradicinio auditorinio mokymo papildymas. Autorę domina būtent šis VMA aspektas.

Straipsnyje apžvelgiami pagrindiniai VMA tipai, ju naudojimas Lietuvos aukštosiose mokyklose ir aptariamas dvieju tipu mokomuju aplinku - tradiciniu (Web CT) ir aktyvaus mokymosi bendradarbiaujant (FLE3) aplinku praktinis tyrimas. Šios aplinkos buvo sukurtos Matematikos ir informatikos institute ir naudojamos studentų mokymui Vilniaus pedagoginiame universitete. 